\title{
RELATION BETWEEN RESULT AND SIZE OF TRAINING LOADS IN 400-METRE HURDLE RACE OF MEN ${ }^{1}$
}

\author{
Jakub Adamczyk \\ Academy of Physical Education in Warsaw, Warsaw, Poland
}

\begin{abstract}
Jakub Adamczyk. Ph. D. in Biomedical sciences, Tutor at the Theory of Sport Department in the Academy of Physical Education. Research
\end{abstract} interests - sports sciences, issues in the theory of training.

\begin{abstract}
Four-hundred-metre hurdle race is a very complex competition event, and besides classical motor abilities, such as speed, strength and endurance, the important components of it are rhythm, flexibility, coordination and jumping ability. The best competitors cover this distance in less than 50 seconds. The efforts of the hurdlers are connected with very high intensity work and with remarkable increase of acidity in working muscles, that is why four-hundred-metre hurdle race is thought to be one of the most difficult track and field competitions. Contemporary sport is characterized by the intense specialization, and thus training optimization is necessary.

The aim of this research was to establish means of training which are essential to achieve high results in 400-metre hurdle race of men. The research included the data characterizing a one-year training cycle of 25 Polish high sport level $400 \mathrm{~m}$ hurdlers (average result $51.25 \mathrm{~s}$ ). For the analysis TreOb 4.0 computer programme was used and the identified training means groups in 400-metre hurdle race (Iskra, 1995).

For six groups of exercises, a positive relation with the sport results was found in all periods when they were applied. Exercises of racing power (including multi-jumps) over 40 metres were in this group as other exercises as Medium interval special endurance, Interval rhythm and Long rhythm endurance.

Similar research performed by J. Iskra (2001) shows common elements which prove that some of the training means have influence on the sports results. In each of the stages, a high correlation was ascribed to the means developing special endurance. High correlation was characteristic of the race of sub-maximum intensity, rhythm long endurance (8 and more hurdles). Significant relation with the result was also found in the racing endurance. The results also demonstrate the significance and importance of the interval racing training means.

Undoubtedly, analysing data we must have in mind the different reaction of competitors to applied training loads which are essential for high results in the 400-metre hurdle race. Such training prepares competitors for a high intensity work load under the conditions of increasing fatigue and muscle acidity. After taking the individualization of the training process into consideration, the data collected can become the model of training for $400 \mathrm{~m} H$ runners representing high sport level.
\end{abstract}

Keywords: athletics, training loads, 400-metre hurdle race of men.

\footnotetext{
The work was done at the Theory of Sport Department at the Academy of Physical Education in Warsaw within I.30 project, financed by the Ministry of Science and Higher Education.
}

\section{INTRODUCTION}

I n sport training a variety of exercises is used. They can have either broad, oriented or special influence. However, not all of them have the same influence on the competitor's participation skills. As the specialization requirements of a competitor increase, it is essential to make the right choice of the load and apply those training means, which have the highest influence on achieving high sports results. Such knowledge for coaches can be an outstanding guide and tool to permanent improvement of the coaching skills (Dick, 2000).

Four-hundred-metre hurdle race is included into competitions of speed-strength character. Along this distance the competitor has to clear ten hurdles, which are one yard $(91.4 \mathrm{~cm})$ high they are at 35-metre intervals. This competition event is highly complex and besides classical motor abilities, such as speed, strength and endurance, 
the important components of it are rhythm, flexibility, coordination and jumping ability. Its duration (about 50 seconds) and a very high intensity of the required effort make the four-hundred-metre hurdle race one of the most difficult track and field competitions. That makes training in this event a very complex process.

Unfortunately, research literature involves the issues of training single athletes, without any academic verification of the effectiveness of exercises applied. Thus the aim of this study was to establish the training means, which have the highest influence on the results in 400-metre hurdle race of men.

\section{METHODS}

The research included the data characterizing a one-year cycle of training of Polish high-level 400-metre hurdlers. The research subjects were a group of 25 competitors, including medal winners of the Polish and European championships, the finalists of the Olympic Games, world championships, record holders and Polish representatives in the senior category as well as medal winners of the junior category master events. The competitors' characteristics are presented in Table 1.

For the analysis TreOb 4.0 computer programme was used. The programme had been elaborated at the Theory of Sport Depertment at the Academy of Physical Education in Warsaw (Sozański, Śledziewski, 1995). The training means groups were identified as described by J. Iskra (1995).

The periodization used in the study was an annual cycle (AC). For the detailed analysis of the relation between the realized training load during a year, two periods were distinguished in the macro cycle: the preparation period and the starting period (SP). The preparation period was divided into: the general preparation sub-period (GPP) and the special preparation sub-period (SPP). The time of each period was arranged as follows: for GPP - from the beginning of the one-year cycle until January 31, for SPP - from February 1 until May 31 and for SP from June 1 until the end of the cycle.

The relation between the load and the sport result was estimated by means of Pearson's cor-
Table 1. Basic data characterizing the researched group

\begin{tabular}{|c|c|c|c|c|c|}
\hline L. $p$. & Competitor & Age, years & Result, s & Height, cm & Weight, kg \\
\hline 1. & P.J. & 26 & 48.17 & 178 & 72 \\
\hline 2. & M.P. & 19 & 49.23 & 183 & 71 \\
\hline 3. & R.S. & 31 & 49.41 & 178 & 69 \\
\hline 4. & J.H. & 28 & 49.69 & 175 & 68 \\
\hline 5. & P.K. & 25 & 49.75 & 188 & 77 \\
\hline 6. & T.K. & 24 & 49.94 & 180 & 76 \\
\hline 7. & K.R. & 25 & 50.08 & 187 & 71 \\
\hline 8. & Z.R. & 24 & 50.46 & 180 & 70 \\
\hline 9. & W.B. & 27 & 51.0 & 188 & 84 \\
\hline 10. & Z.S. & 24 & 51.0 & 182 & 72 \\
\hline 11. & S.B. & 27 & 51.26 & 182 & 72 \\
\hline 12. & G.A. & 20 & 51.28 & 187 & 74 \\
\hline 13. & W.S. & 24 & 51.48 & 191 & 85 \\
\hline 14. & D.P. & 20 & 51.5 & 184 & 80 \\
\hline 15. & P.L. & 22 & 51.51 & 187 & 82 \\
\hline 16. & J.S. & 22 & 51.65 & 177 & 65 \\
\hline 17. & J.A. & 26 & 51.72 & 190 & 84 \\
\hline 18. & A.S. & 30 & 51.86 & 187 & 74 \\
\hline 19. & A.I. & 19 & 52.01 & 184 & 77 \\
\hline 20. & A.K. & 22 & 52.36 & 176 & 72 \\
\hline 21. & B.S. & 22 & 52.82 & 180 & 74 \\
\hline 22. & Ł.K. & 18 & 52.83 & 177 & 72 \\
\hline 23. & T.W. & 23 & 52.90 & 192 & 80 \\
\hline 24. & M.R. & 19 & 53.56 & 176 & 66 \\
\hline 25. & M.D. & 21 & 53.66 & 186 & 80 \\
\hline \multicolumn{2}{|c|}{$\overline{\mathrm{X}}$} & $23.52 \pm 3.49$ & $51.25 \pm 1.40$ & $182.57 \pm 5.41$ & $74.25 \pm 5.76$ \\
\hline
\end{tabular}




\begin{tabular}{|c|c|c|c|c|c|}
\hline \multirow{2}{*}{ Training means } & \multicolumn{4}{|c|}{ Pearson's correlation factor } & \multirow{21}{*}{$\begin{array}{l}\text { Table } 2 \text {. Correlation between } \\
\text { the realized classified trai- } \\
\text { ning load and the sport result } \\
\text { in the one-year cycle (AC) as } \\
\text { well as in the separate peri- } \\
\text { ods (GPP, SPP, SP) }\end{array}$} \\
\hline & AC & GPP & SPP & SP & \\
\hline Speed interval endurance & $0.339 * *$ & $0.318^{*}$ & & & \\
\hline Special short endurance & $0.278^{*}$ & & & $0.255^{*}$ & \\
\hline Medium interval special endurance & $0.566 * * *$ & $0.319^{*}$ & $0.530 * * *$ & $0.481 * * *$ & \\
\hline Mixed special endurance & $0.478 * * *$ & $0.290 *$ & $0.473 * * *$ & & \\
\hline Long rhythmic endurance & $0.486 * * *$ & & $0.493 * * *$ & $0.369 * *$ & \\
\hline Interval rhythm & $0.527 * * *$ & $0.440 * * *$ & $0.494 * * *$ & $0.597 * * *$ & \\
\hline Continuous races & $0.264 *$ & & $0.441 * * *$ & & \\
\hline Racing power (more than 40 metres) & $0.464 * * *$ & $0.523 * * *$ & $0.278^{*}$ & $0.370 * *$ & \\
\hline Multi-jumps (more than 40 metres) & $0.658^{* * *}$ & $0.540 * * *$ & $0.539 * * *$ & $0.609 * * *$ & \\
\hline Half-squats with sub-maximum load & $0.393 * *$ & & $0.423 * * *$ & $0.317 *$ & \\
\hline Standing on toes with a load & & $0.263 *$ & & $-0.273^{*}$ & \\
\hline Stepping up & & & & $0.369 * *$ & \\
\hline Hurdle marches & $0.260 *$ & & & $0.359 * *$ & \\
\hline Arms muscle and shoulder girdle power & & & $0.290 *$ & & \\
\hline Legs muscle exercises & $0.357 * *$ & $0.432 * * *$ & $0.322 *$ & & \\
\hline Multi-event throws & & & $0.292 *$ & & \\
\hline General fitness exercises & & & $0.398 * *$ & & \\
\hline $\begin{array}{l}\text { The number of participations in } 60 \text { up to } \\
200 \text {-metre (sprint) races }\end{array}$ & & & & $-0.474 * * *$ & \\
\hline $\begin{array}{l}\text { The number of participations in } \\
400 \text {-metre hurdle race }\end{array}$ & $0.278^{*}$ & & & $0.406^{* *}$ & \\
\hline
\end{tabular}

relation factor. The results at the levels of $0.05 \%$, $0.01 \%$ and $0.001 \%$ were assumed as significant.

\section{RESULTS OF STUDY}

In the group of hurdlers whose training was observed many correlations were found between the training volume according to the means groups and the sport result. The detailed results of the correlation analysis for those training means groups which had a beneficial influence on the result were presented in Table 2.

\section{DISCUSSION}

The distinguished groups of training means which have the greatest influence on the increase of the 400-metre hurdle race sport level provide guidelines for their use in training. Unfortunately, this subject did not receive much interest among researchers. However, in such periodicals as Track Coach, New Studies in the Athletics or Track Field and News we find information about the hurdlers' training system, the issue of distinguishing the most effective solutions remains almost intact. Even the analysis of the best competitors' training does not allow sharing it with the wider population.

Individual reactions on the applied training load urge us to make very careful judgment about the training load efficiency. Attempts taken at the work to distinguish three periods dividing the oneyear training cycle help estimating the training influence more precisely. It is especially obvious in the differences between the cycle correlations and the separate stages.

Similar analysis was made by J. Iskra (2001) for a group of 33 hurdlers on the 400 -metre distance. The competitors' sport level amounted to $\overline{\mathrm{x}}=51.25 \mathrm{~s}( \pm 1.46)$ and the age $\overline{\mathrm{x}}=22.1$ $( \pm 2.33)$. The characteristics of the group show almost identical sport level of both groups and significant similarity of the age (in case of J. Isk$\mathrm{ra}$ - the variation in the age was lower). However, J. Iskra proposes slightly different classification of the training means group and the results provide a possibility of comparison.

The author found positive correlations between the training loads and the results in the scope of the following training means groups:

- For AC - the special endurance, racing power, RR muscle and shoulder girdle power, 8 - 12 hurdle races.

- For GPP - racing speed, racing power, RR muscle and shoulder girdle power.

- For SPP - special endurance, racing power, RR muscle and shoulder girdle power, 8-12 hurdle races.

- For SP - racing power (over 40 metres), RR muscle and shoulder girdle power, 8-12 hurdle races, hurdle races at changeable rhythm.

Negative influence was indicated for the racing speed at AC and SP as well as for technical exercises done on the run at GPP. 
The analysis of both studies and their common elements prove that some of the training means have a more remarkable influence on the sports results. For each of the stages, a high correlation was ascribed to the means developing special endurance as in the stages of running at sub-maximum intensity and longer the rhythmic endurance ( 8 and more hurdles). The significance of these means in the hurdlers' training does not raise any doubts or require any comment.

A close relation with the result was also indicated in the racing power and weight exercises with a significant component of endurance estimated by the length of the stage (over 40 metres) or its time. These exercises are valuable when a jumping joint is activated by transition from a lowered position of the heel to pushing away from the ground with fingers. Such exercises enable developing the endurance and power of the lower limbs. It is worth noting that positive relations of exercises of this type with the result were also established for hurdlers specializing in the $110 \mathrm{~m}$ hurdle run (Iskra, 2001).

In the research the interval means of racing training appeared to be quite important. However, it is necessary to remember that such stringent training means of the interval character often have no application in the training of hurdlers of lower sports level. Similarly, the weaker competitors sometimes omit the long rhythmic endurance training not applying it in their training sessions.

In both studies the influence of maximum speed training in some stages was indicated. It contradicts to the general opinion that at the 400-metre hurdle race, which is a speed-oriented competition, the speed training should be essential (Black, 1988). It seems that the development of the speed ability is very important and the competitors of the high-speed level are predestined for reaching high results (Iskra, 1999). Certainly such a view must dominate in the process of qualification for $110 \mathrm{~m} \mathrm{H}$ run (McFarlane, 1988; Sparrey, 1997). No matter how the speed of the run of the best competitors in both of hurdle distances is similar $(\sim 8.5 \mathrm{~m} / \mathrm{s})$, the character of use high-speed abilities is slightly different. Above all it is necessary to remember that speed enables not only finishing the race as soon as possible but also clearing the hurdle itself. The speed must be followed by the technique, otherwise it will have no effect on the result. It can even cause frequent problems with finishing the race or rhythm disorder on the distance. In $400 \mathrm{~m}$ hurdle run there are differences in speed at the initial and final phases of the run.
The appearance of versatile means in the analysis (Arms and Legs muscle power, multi-event throws or oriented means (standing on toes with a load, half knee bends), which indicate the connection with the result, proves that not only the special means have an impact on the sports level. Polish climatic conditions also do not allow relying only on the special means (Iskra, 2001). The remaining training means do not only supplement the previous ones, but they also - as substitutes allow shaping certain training skills. High relations were found in interval rhythms that, with access to indoor training, create outstanding possibilities for carrying out the rhythm training in the winter period (Warburton, 1985; Reinbert, 1987; Warden, 1988; Iskra, 2001).

Contemporary training tendencies seem to show that on the 400 hurdles run, the special and hurdle endurance with racing power exercises are dominant in training (Alejo, 1993; Lindeman, 1995; Boyd, 2000; Adamczyk, 2007 b).

In this context, not the legitimacy of some training means application should be assessed but its proportion during a year. It is difficult to imagine the hurdle training limited only to several racing and power means.

Undoubtedly, for the high sport results for the 400-metre hurdlers such racing means, as those of the greatest intensity are essential. Interval training, special endurance or rhythm endurance (especially the long one) prepare the competitors for high intensity efforts under the conditions of increasing fatigue and muscle acidity.

Research that cannot be applied in sport is of lower value. The results presented in this study show certain patterns of high-sport level hurdlers training which show the connection of "art of coaching" and science (De Swardt, 2007). Such analysis is also possible for a single competitor (Adamczyk, 2007 a) with detailed recording of the load performed and relating it to the achieved sport result. The analysis should also include a long period to exclude randomness. The results of such analyses would provide significant information, which could help planning further training of the season.

\section{ACKNOWLEDGEMENTS}

The work was performed at the Theory of Sport Department the Academy of Physical Education in Warsaw within I.30 project, financed by the Ministry of Science and Higher Education. 


\title{
REFERENCES
}

Adamczyk, J. (2007 a). Analysis of a many years fourhundred-metre hurdler's training. In Moloda Sportywna Nauka Ukrainy. L'viv State University of Physical Culture. P. 129.

Adamczyk, J. (2007 b). Obciażenie treningowe zawodników o różnym poziomie sportowym trenujacych bieg na 400 m przez płotki: Ph. D. Thesis. Warsaw: Academy of Physical Education.

Alejo, B. (1993). Weight training for the 400 hurdler. Track Technique, 123.

Black, W. (1988). Training for the $400 \mathrm{~m}$. Track Coach, 102, 3243-3245.

Boyd, R. (2000). Components of the 400 m hurdles. Track Coach, 151, 4822-4825.

Dick, F. W. (2000). Sports Training Principles. London.

Iskra, J. (1999). Bieg na 400 m przez płotki. Rzeszów.

Iskra, J. (2001). Morfologiczne i funkcjonalne uwarunkowania rezultatów w biegach przez płotki. Katowice: Academy of Physical Education.

Iskra, J. (1995). Rejestr grup środków treningu w biegu na 400 m ppł. In Sozański, H. and Śledziewski, D. (Eds.),
Obciażenia treningowe - dokumentowanie i opracowanie danych. Warszawa: COS RCMSKFiS. P. 84-91.

Lindeman, R. (1995). 400 meter hurdle theory. Track Coach, 131, 4169-4171.

McFarlane, B. (1988). The Science of Hurdling. Ottawa: Canadian Track and Field Assosation.

Reinbert, W. (1987). Trainings methodische Hinweise zur Einfuhrung der 300-mmHurdenstrecke in der weiblichen Jugend B. Leichtathletik, 51-52, 760-762.

Sozański, H., Śledziewski, D. (Eds.). (1995). Obciażenia treningowe - dokumentowanie i opracowanie danych. Warszawa: COS RCMSKFiS

Sparrey, K. R. (1997). Identifying and developing elite hurdles in the United States. Track Coach, 141, 45054510 .

De Swardt, A. (2007). Top Elite Performance. Track Coach, 184, 5885-5887.

Warburton, D. (1985). The $400 \mathrm{~m}$ hurdles - the development of effective technique. Athletics Coach, 9, 21-25.

Warden, P. (1988). Planning Training for the Sprints \& Hurdles. Track Coach, 105, 3351-3354.

\section{M BARJERINIO BE்GIMO SPORTININKŲ REZULTATŲ IR JŲ PRATYBŲ KRŪVIO APIMTIES RYŠYS}

\author{
Jakub Adamczyk \\ Varšuvos kūno kultūros akademija, Varšuva, Lenkija
}

SANTRAUKA

$400 \mathrm{~m}$ barjerinis bėgimas yra labai sudètinga varžybų rungtis — be klasikinių motoriniu igūdžių (greičio, jègos ir ištvermès) čia labai svarbios tokios savybès kaip ritmiškumas, lankstumas, koordinacija ir šoklumas. Geriausi varžybų dalyviai ši nuotoli ịveikia per mažiau nei $50 \mathrm{~s}$. Sportininkas tokių varžybų metu atlieka labai intensyvų darbą, jo raumenyse smarkiai padidejja rūgštingumas, dèl to $400 \mathrm{~m}$ barjerinis bejgimas laikomas viena iš pačių sunkiausių lengvosios atletikos rungčių.

Šio tyrimo tikslas - nustatyti treniravimo priemones, būtinas norint pasiekti puikių $400 \mathrm{~m}$ vyrų barjerinio bėgimo rezultatų. Straipsnyje pateikiami didelio meistriškumo $400 \mathrm{~m}$ barjerinio bẻgimo sportininku ( 25 lenku) vieneriu metų treniravimosi ciklo duomenys (vidutinis rezultatas - 51,25 s). Duomenų analizei atlikti naudota TreOb kompiuterinė programa, kuria buvo išskirtos treniravimosi vidurkių grupès (Iskra, 1995).

Kiekvieną kartą testuojant buvo aptinkamas teigiamas ryšys tarp šešiu pratimų grupių ir sportinių rezultatų. $40 \mathrm{~m}$ lenktynių, greitumo jègos pratimai (taip pat daugiašuoliai) buvo derinami su kitais specialiosios ištvermès pratimais, atliekami ilgesnès trukmès bėgimo pratimai.

Panašūs J. Iskros (2001) tyrimo rezultatai rodo, kurios treniravimo priemonès yra veiksmingesnès siekiant sportinių rezultatų. Kiekvienu etapu pastebėjome didelę koreliaciją tarp specialiosios išttvermès lavinimo rodikliu vidurkių, kai buvo bėgama submaksimaliu intensyvumu, ritmiškai lavinant ištvermę (iveikiant 8 ir daugiau barjerų). Didelè rodiklių koreliacija nustatyta submaksimalaus intensyvumo lenktynių etapais, lavinant bėgimo ritmą.

Analizuojant duomenis būtina atsižvelgti ị tai, kad sportininkai skirtingai reaguoja i pratybų krūvius, bet galima tvirtai teigti, kad, siekiant geru $400 \mathrm{~m}$ barjerinio bėgimo rezultatų, ypač svarbios intervaliniu pratybu priemonės. Toks treniravimas parengia sportininkus ivveikti padidejjusi nuovargị ir raumenų rūgštingumą. Tyrimo rezultatai parodé, kad toks rengimo būdas galètų tapti $400 \mathrm{~m}$ barjerinio bėgimo aukšto lygio sportininkų rengimo modeliu.

Raktažodžiai: atletika, vyrų $400 \mathrm{~m}$ barjerinis bėgimas, pratybų krūviai.

Gauta 2008 m. birželio 9 d.

Received on June 9,2008

Priimta 2009 m. lapkričio $10 \mathrm{~d}$.

Accepted on November 10, 2009
Jakub Adamczyk

Academy of Physical Education

(Kūno kultūros akademija)

ul. Marymoncka 34 00-968 Warsaw, Poland

Telephone and Fax number: +48 228344154

Mobile phone: +48 501932389

E-mail jakub.adamczyk@awf.edu.pl; kubimacher@o2.pl 